\title{
Ekonomik Büyüme, Enerji Tüketimi ve Karbon Emisyonları İlişkisi: Çin Örneği
}

\author{
Economic Growth, Energy Consumption and Carbon Emissions Relation: The Case \\ of China
}

\author{
Dr. Öğr. Üyesi Musa ATGÜR
}

\begin{abstract}
$\ddot{\mathbf{O} z}$
Ekonomik büyüme ve gelişmeye bağlı olarak yüksek düzeyde enerji tüketiminin çevre üzerindeki etkileri tartışılmaktadır. Ekonomik ve sosyal yaşamda enerji kullanımının giderek artması çevre kalitesini olumsuz etkilemekte, yaşanılan çevre açısından önemli sorunları da beraberinde getirmektedir. Bu bağlamda, ekonomik gelişme ve büyümenin sürdürülebilirliğini esas alan yaklaşımlar gittikçe önem kazanmaktadır. Bu çalışma, Çin'de 1971-2014 döneminde sürdürülebilir büyüme bağlamında ekonomik büyüme ve enerji kullanımı ile karbon emisyonları arasındaki ilişkiyi incelemeyi amaçlamaktadır. Çalışmada, yıllık veriler kullanılmış olup Sıradan En Küçük Kareler tahmin yöntemi ile beraber Johansen Eşbütünleşme ve Hata Düzeltme Modeli Granger nedensellik test yöntemleri uygulanmıştır. Elde edilen bulgular, Johansen Eşbütünleşme test ve Sıradan En Küçük Kareler yöntemi tahmin sonuçlarının istatistiksel olarak anlamlı sonuçlandığını göstermektedir. Fakat, Hata Düzeltme Modeli Granger nedensellik test sonuçları anlamlı bulunmamıştır. Bulgular, Çin'de ekonomik büyümenin ve enerji tüketiminin karbon emisyonları üzerinde etkili olduğunu göstermekte ve Sürdürülebilir Ekonomik Büyüme yaklaşımının Çin için önemli olduğunu ortaya koymaktadir.
\end{abstract}

Anahtar Kelimeler: Ekonomik büyüme, enerji tüketimi, karbon emisyonları

Makale Türü: Araştırma

\begin{abstract}
It is discussed the effects on the environment of energy use at a high level depending on economic growth and development. It is the cause negative effects on air quality, and it brings with it important problems in terms of the environment we live in increasing of energy use in economic and social life. In this context, approaches are becoming more and more important based on the sustainability of economic development and growth. In this paper, the relationship between economic growth, energy consumption and carbon emissions in the context of sustainable growth in China during the period 1971-2014. The annual data were used in the paper, Johansen Cointegration, Ordinary Least Squares estimation, Error Correction Model Granger causality test methods have been performed. Obtained the findings show that the results of the Johansen Cointegration test and Ordinary Least Squares estimation are statistically significant. However, Error Correction Model Granger causality test results were not found to be significant. The findings show that economic growth and energy consumption has an impact on carbon emissions in China and reveals that the Sustainable Economic Growth approach is important for China.
\end{abstract}

Keywords: Economic growth, energy consumption, carbon emissions

Paper Type: Research

${ }^{1}$ Balıkesir Üniversitesi, İktisadi ve İdari Bilimler Fakültesi, musa.atgur@balikesir.edu.tr. 


\section{Giriş}

Gelişmiş ve gelişmekte olan pek çok ülkede, ekonomik faaliyetlerin çevre üzerindeki etkileri sürekli olarak tartışılmaktadır. Ekonomik faaliyetlerdeki artış, çevre kirliliğine neden olmakta ve sosyal maliyetler de önemli ölçüde artmaktadır. Bu bakımdan, sürdürülebilir ekonomik büyümeyi merkezine alan ekonomik yaklaşımlar günümüzde daha önemli hale gelmektedir.

Günümüzde, enerji kaynaklarının etkin ve verimli bir biçimde kullanımı ekonomik gelişme üzerinde etkili olmaktadır. Bu gelişmenin, çevre üzerindeki olumsuz etkilerinin minimum düzeye düşürülmesini esas alan sürdürülebilir ekonomik büyümenin gerçekleştirilmesi gittikçe önem kazanmaktadır.

Sürdürülebilirlik kavramı, ekolojik, sosyal ve ekonomik olmak üzere üç farklı açıdan değerlendirilmektedir. $\mathrm{Bu}$ bakımdan, ekonomik büyümenin sürdürülebilir olabilmesi için ekolojik, sosyal ve ekonomik yönlerinin de var olması gerekmektedir. Sürdürülebilir ekonomik büyüme teorisine, Dasgupta ve Heal (1974), Solow (1974) ve Stiglitz (1974) önemli katkılar sağlamışlardır. Her üç yazar da, önerdikleri modellerde refahın maksimizasyonunu esas almış, sınırlı bir doğal kaynak düzeyi ile elde edilebilecek maksimum fayda düzeyini göstermişlerdir. Solow (1974), belirli koşullar altında refahın sağlanabilmesi için, toplam sermaye stokunun korunması gerektiğini savunmuştur. Buna göre, doğal sermayenin tükenmesi durumunda, üretken sermaye ya da diğer sermaye türlerine yapılan ilave yatırımlar ile bu açık dengelenmektedir. Üretken sermaye düzeyi korunarak, kişi başına mümkün olan maksimum sabit tüketim düzeyi zaman içinde elde edilebilir. Bu bakımdan, ekonomik sürdürülebilirlik kavramı, kaynakların mevcut nesiller ve gelecek nesiller için en yüksek refah düzeyini sağlayacak biçimde tahsis edilmesi olarak tanımlanmaktadır (Markulev ve Long, 2013, s. 2-4).

Öte yandan, 2012 yılında Brezilya'nın başkenti Rio de Janeiro'da düzenlenen Birleşmiş Milletler Sürdürülebilir Kalkınma Konferansı'nda ilk defa "Yeşil Büyüme" kavramı ortaya atılmıştır. Yeşil büyüme kavramı, düşük karbon emisyonlarını ve sürdürülebilir kalkınma hedeflerini, yoksulluğun azaltılması ve ekonomik büyüme ile birleştirmeyi hedefleyen bir kazankazan çözümü olarak ortaya çıkmıştır (Resnick ve Thurlow, 2012).

Ekonomik büyüme ve çevre kirliliği ilişkisinin teorik boyutlarından biri Çevresel Kuznets Eğrisidir. Çevresel Kuznets Eğrisi, kişi başına düşen gayrisafi yurtiçi hasıla (GSYİH) ile çevresel kirlilik arasındaki ilişkiyi açıklayan bir teoridir. Buna göre, ekonomik büyümenin önceki aşamalarında çevresel kirliliğin arttı̆̆ ifade edilmektedir. Ancak, kişi başına düşen gelir düzeyi arttıç̧a bir süre sonra söz konusu eğilim tersine dönmekte, yüksek gelir düzeyine ulaşıldıktan sonra ekonomik büyüme çevresel koşullarda iyileşmeye neden olmaktadır. Bu durumda, kişi başına gelirin ters U biçimli çevresel etki göstergesi var olduğu belirtilmektedir. Söz konusu göstergenin logaritmik değeri, gelirin logaritmik değerinin ikinci dereceden bir fonksiyonu olarak modellenmektedir (Stern, 2003, s. 1). Çevresel Kuznets Eğrisi, belirli bir kirletici faktörün çevre üzerinde bıraktığı emisyon veya yoğunlaşma düzeylerinin, bir ülkenin veya bir şehrin kişi başına düşen gelirinin zamanla arttığını ve daha sonra maksimum seviyeye ulaştığını gösteren ampirik bir bulgudur. Maksimum noktasından sonra kişi başına düşen gelir büyümeye devam ettikçe emisyon düzeyi de azalmaktadır (Eugenio ve Roberto, 2009, s. 6). Bu bakımdan, ekonomik büyüme en yüksek düzeye ulaştı̆̆ında uzun dönemde, çevre kalitesini olumlu yönde etkilemektedir.

Doksanlı yıllarda, Çevresel Kuznets Eğrisinin geçerliliğini ekonometrik yöntemler kullanarak inceleyen çalışmalarda Çevresel Kuznets Eğrisinin varlığı üzerinde önemli bulgular elde edilmiştir. Bu çalışmalar; Grossman ve Krueger (1995), Shafik ve Bandyopadhyay (1992), Panayotou (1993), Selden ve Song (1994), Shafik (1994), Holtz-Eakin ve Selden (1995), Vincent (1996) olarak ifade edilmektedir. 
Son çeyrek yüzyılda, ekonomik büyüme ve gelişme açısından önemli bir performans gösteren Çin'de hızlı büyüme ile birlikte çevre kirliliği sorunları ortaya çıkmıştır. Son yıllarda Çin'de çevre kirliliği ile mücadelede yeni tedbirler alınmakta, özellikle, temiz enerji kullanımının teşvik edilmesi ve taşıt kullanımının ortaya çıkardığı kirliliğin önlenmesi yönünde önemli kararlar alınmakta ve yatırımlar yapılmaktadır.

Çalışmanın ekonometrik kısmında kullanılan veri seti, beşer yıllık periyotlar için grafiğe dönüştürülmekte, Grafik 1 ve Grafik 2 olmak üzere iki farklı grafikte gösterilmektedir. Çin'de ekonomik büyüme ve birincil enerji tüketimi serilerinin 1971-2014 dönemi için eğilimi Grafik 1'de gösterilmektedir. Grafik 1'e göre, 2000 yılından itibaren hızlı bir ekonomik büyüme sürecine giren Çin'de, aynı yıldan itibaren birincil enerji tüketiminde de artış trendinin başladığı gözlenmektedir.

Grafik 1. Ekonomik büyüme ve birincil enerji tüketimi (Çin)

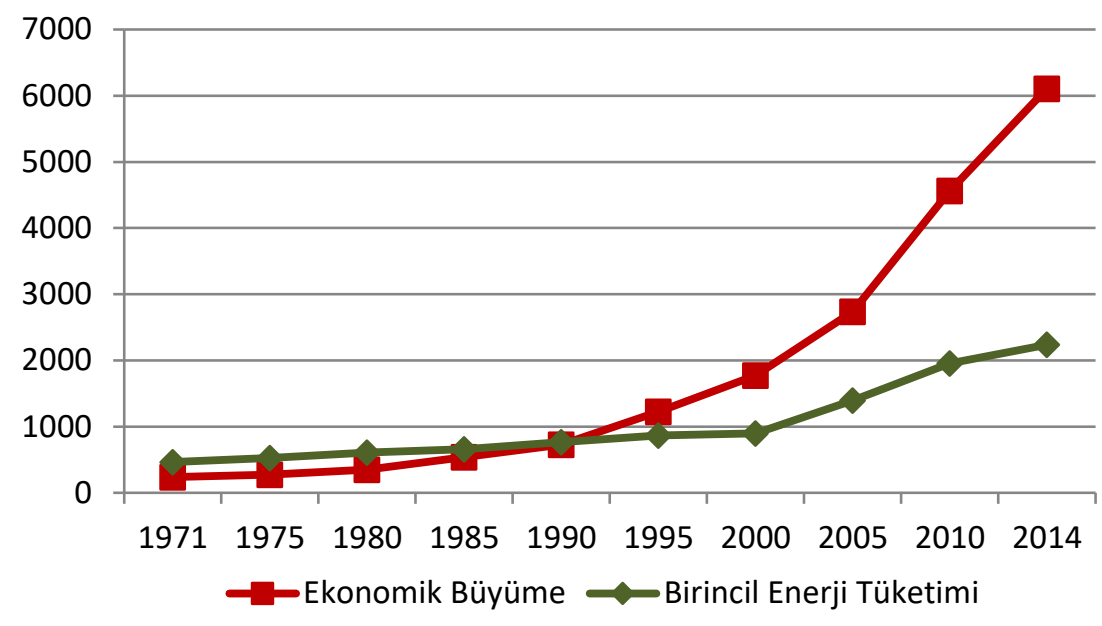

Grafik 2'de, 1971-2014 döneminde Çin'de karbon emisyonları serisinin eğilimi gösterilmektedir. Buna göre, 2000 yılı sonrasında karbon emisyonlarında önemli bir artış gerçekleştiği tespit edilmektedir.

Grafik 2. Karbon emisyonları (Çin)

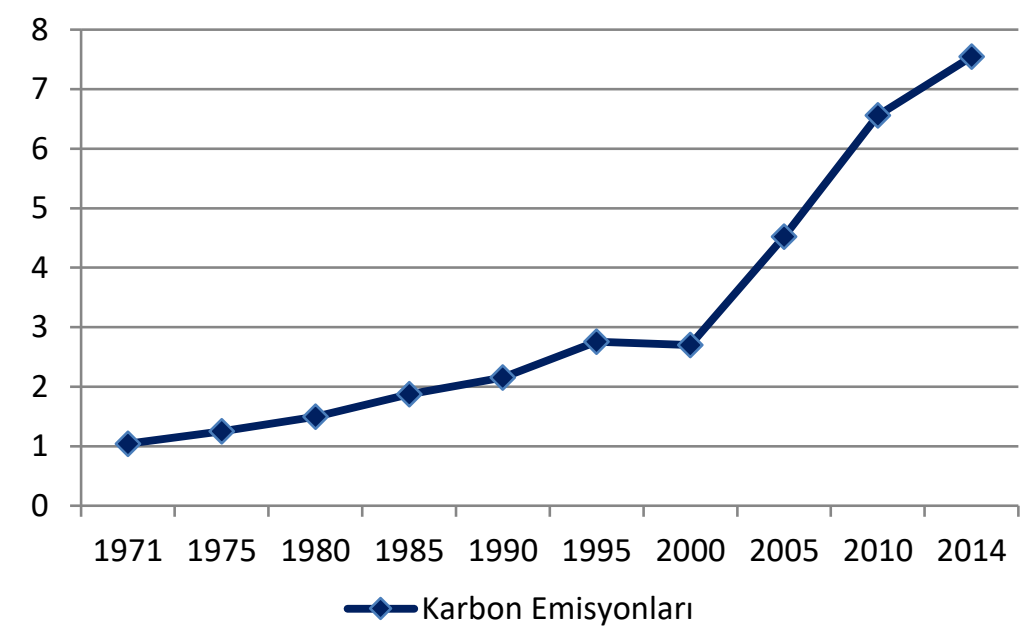

Grafik 1 ve Grafik 2 olmak üzere her iki grafik de birbiriyle karşılaştırıldığında, ekonomik büyüme serisi ile karbon emisyonları serisi arasında benzerliklerin bulunduğu görülmektedir.

Çin'de, hızlı nüfus artışı ve yüksek düzeyde ekonomik büyüme çevreyi olumsuz etkilemektedir. Başkent Pekin gibi büyük ve merkezi şehirlerde önemli çevre kirliliği sorunları 
ortaya çıkmaktadır. Çin'in, özellikle son çeyrek yüzyılda gösterdiği ekonomik büyüme performansı ile birlikte büyük şehirlerde hava kirliliğinin de önemli düzeyde artması, ekonomik büyüme, enerji tüketimi ve karbon emisyonları arasındaki ilişkinin incelenmesini gerektirmektedir.

Bu bakımdan bu çalışmanın, ekonomik büyüme ve çevre kirliliği ilişkisi literatürüne teorik ve ekonometrik uygulama yönünden katkı sağlayabileceği düşünülmektedir. Çalışmada, Çin'de ekonomik büyüme ile karbon emisyonları farklı boyutları ile birlikte incelenmiş, yeni bir ekonometrik model vasıtası ile farklı ekonometrik yöntemler kullanılarak önemli bulgular elde edilmiştir.

Çin'de ekonomik büyüme, enerji tüketimi ve karbon emisyonları ilişkilerinin incelendiği bu çalışmanın ilk kısmında, ekonomik büyüme ve karbon emisyonları ilişkisi üzerine literatürdeki çalışmalar incelenecektir. İkinci kısımda, Çin'de ekonomik büyüme, enerji tüketimi ve karbon emisyonları ilişkisi üzerine ekonometrik bir uygulama yapılacaktır. Son kısımda, elde edilen bulgular tartışılacaktır.

\section{Ekonomik Büyüme, Enerji Tüketimi ve Karbon Emisyonları İlişkisi Literatürüne Bakış}

Bu kısımda, ekonomik büyüme, enerji tüketimi ve karbon emisyonu ilişkilerini inceleyen farklı ülkeler için yapılan çalışmalar incelenecektir. Bu amaçla ilk kısımda belirtilen ilişkinin varlığına yönelik gelişmiş ülkeler ve Avrupa Birliği (AB) ülkelerini inceleyen çalışmalar, ikinci kısımda ise az gelişmiş ülkeleri inceleyen çalışmalar incelenecektir.

\subsection{Gelişmiş Ülkeler ve Avrupa Birliği (AB) Üzerine Yapılan Çalışmalar}

Gelişmiş ülkeler literatüründe var olan çalışmalar, ekonomik büyüme, enerji tüketimi ve çevre kirliliği ilişkisini farklı yönlerden incelemişlerdir. Bu çalışmalardan Richmond ve Kaufmann (2006), OECD üyesi ülkelerde ve OECD üyesi olmayan ülkelerde, gelir düzeyi ve enerji kullanımı ile karbon emisyonları arasındaki ilişkiyi panel veri analizi yöntemini kullanarak incelemişlerdir. Çalışma bulguları, OECD üyesi olmayan ülkelerde gelir düzeyinin ve enerji kullanımının, karbon emisyonlarını etkilediğine işaret etmektedir.

Öte yandan Ang (2007), Fransa'da 1960-2000 döneminde, enerji tüketimi ve ç1kt1 ilişkisini incelemiştir. Elde edilen sonuçlara göre, uzun dönemde ekonomik büyümeden, enerji kullanımı ve kirlilik artışı yönüne doğru nedensellik ilişkisi tespit edilmektedir.

Aydın (2013), G7 ülkelerinde 1991-2009 döneminde karbon emisyonları, yenilenebilir enerji tüketimi, ekonomik büyüme ve nüfus yoğunluğu arasındaki ilişkiyi incelemiştir. Çalışmada, Johansen-Fisher eşbütünleşme, panel Granger nedensellik, etki-tepki testleri ve panel en küçük kareler tahmin yöntemleri kullanılmıştır. Aydın (2013)'ün bulduğu sonuçlar, G7 ülkeleri arasında farklılıklar olduğunu göstermektedir. Buna göre, ekonomik büyüme, enerji tüketimi ve nüfus yoğunluğunun, karbon emisyonlarının nedeni olduğu tespit edilmektedir.

To vd. (2013) Avustralya'da enerji tüketimi ve ekonomik büyüme ilişkisini, 1970-2011 dönemi için, Sınır testi ve Granger nedensellik test yöntemlerini kullanarak incelemişlerdir. Çalışmanın ekonometrik modeli için; GSYİH, işgücü, sermaye, beşeri sermaye ve enerji tüketimi değişkenleri belirlenmiştir. Çalışmanın sonuçlarına göre, Avustralya'da belirtilen dönemde enerji tüketimi ile ekonomik büyüme arasında zayıf bir ilişkinin var olduğu tespit edilmektedir.

Ucan vd. (2014), on beş Avrupa Birliği (AB) ülkesinde 1990-2011 dönemi için, yenilenebilir enerji tüketimi ile ekonomik büyüme arasındaki ilişkiyi incelemişlerdir. Panel Granger nedensellik test yönteminin kullanıldığı çalışmada, yenilenebilir enerji tüketimi, yenilenemeyen enerji tüketimi, ekonomik büyüme ve gaz emisyonu değişkenleri belirlenerek ekonometrik model kurulmuştur. Elde edilen bulgulara göre, yenilenebilir enerji tüketimi ile ekonomik büyüme arasında nedensellik ilişkisinin varlığı tespit edilmektedir. 
Kasperowicz (2015), AB ülkelerinde ekonomik büyüme ile karbon emisyonları ilişkisini 1995-2012 dönemi için incelemiştir. Çalışmada ekonometrik modelleme için GSYİH ve karbon emisyonu değişkenleri belirlenmiş olup, panel veri analizi yöntemi kullanılmıştır. Elde edilen bulgular, AB ülkelerinde belirtilen dönemde GSYİH ile karbon emisyonları arasında ilişkinin var olduğuna işaret etmektedir.

Obradović and Lojanica (2017), Güney Doğu Avrupa ülkeleri ile Yunanistan ve Bulgaristan'da enerji kullanımı, karbon emisyonları ve ekonomik büyüme ilişkisini 1980-2010 dönemi için incelemişlerdir. Hata Düzeltme Modeli (ECM) yönteminin kullanıldığı çalışmanın ekonometrik modeli için, kişi başına GSYIH, kişi başına sabit sermaye formasyonu ve kişi başına enerji kullanımı değişkenleri belirlenmiştir. Elde edilen bulgular, her iki ülkede uzun dönemde enerji kullanımı ve karbon emisyonlarından ekonomik büyümeye doğru nedensellik ilişkisinin var olduğunu ortaya koymaktadır. Buna karşılık, kısa dönemde enerji kullanımı ve ekonomik büyüme arasında nedensellik ilişkisi bulunmamaktadır.

\subsection{Az Gelişmiş Ülkeler Üzerine Yapılan Çalışmalar}

Az gelişmiş ülkeler üzerine yapılan çalışmalardan Soytas ve Sarı (2009), Türkiye'de ekonomik büyüme, karbondioksit emisyonları ve enerji tüketimi ilişkilerini uzun dönemli Granger nedensellik yöntemi ile incelemişlerdir. Elde edilen bulgular, Türkiye'de ekonomik büyüme ile karbondioksit emisyonları arasında ilişki olmadığını göstermektedir.

Acaravcı ve Ozturk (2010), Türkiye için 1968-2005 döneminde, ekonomik büyüme, karbon emisyonları, enerji tüketimi ve istihdam oranı arasındaki uzun dönemli ilişkiyi incelemişlerdir. Ardışık Gecikmesi Dağıtılmış (ARDL) Sınır Testi sonuçları, uzun dönemli ilişkinin varlığını göstermekte iken, Granger nedensellik test sonuçları, kişi başına karbon emisyonu ve kişi başına enerji tüketimi ile kişi başına reel GSYİH arasında nedensellik ilişkisinin var olmadığını göstermektedir.

Apergis ve Payne (2010), Bağımsız Devletler Topluluğu'nun on bir ülkesinde, 1994-2004 dönemi için, karbondioksit emisyonları, enerji tüketimi ve ekonomik büyüme ilişsisini incelemişlerdir. Bulgular, enerji tüketimi ve karbondioksit emisyonları arasında uzun dönemli bir ilişkinin var olduğunu göstermektedir. Ayrıca, enerji tüketimi ile ekonomik büyüme arasında çift yönlü nedensellik ilişkisinin varlığı tespit edilmektedir.

Chang (2010), Çin'de, karbondioksit emisyonları, enerji tüketimi ve ekonomik büyüme ilişkisini incelemiştir. Sonuçlar, ekonomik büyümenin, enerji tüketimini ve karbondioksit emisyonunu arttırdığ $ı n ı$ göstermektedir.

Menyah ve Wolde-Rufael (2010), Güney Afrika'da, 1965-2006 dönemi için, ekonomik büyüme, kirletici emisyonlar ve enerji tüketimi arasındaki uzun dönemli ilişkiyi ve nedensellik ilişkisini incelemişlerdir. Sınır testi sonuçları, değişkenler arasındaki uzun vadeli ilişkiye işaret etmektedir. Ayrıca, kirletici emisyonlardan ekonomik büyümeye doğru tek yönlü nedensellik ilişkisinin var olduğu tespit edilmektedir.

Niu vd. (2011), sekiz Asya Pasifik ülkesi için, 1971-2005 döneminde ekonomik büyüme, enerji tüketimi ve emisyon ilişkisini incelemişlerdir. Panel veri analiz yönteminin kullanıldığı çalışmadaki bulgular, ekonomik büyüme, enerji tüketimi ve karbon dioksit emisyonları arasında nedensellik ilişkisi bulunduğunu göstermektedir.

Arouri vd. (2012), on iki Ortadoğu ülkesinde ve Kuzey Afrika ülkelerinde, 1981-2005 dönemi için, enerji tüketimi, ekonomik büyüme ve karbondioksit emisyonları ilişkisini incelemişlerdir. Eşbütünleşme test sonuçları, on iki Ortadoğu ülkesinde ve Kuzey Afrika ülkelerinde, uzun dönemde enerji tüketimi ile karbondioksit emisyonları arasında ilişki bulunduğunu göstermektedir.

Siddiqui (2004), Pakistan'da 1970-2003 döneminde enerji ile ekonomik büyüme arasındaki nedensellik ilişkisini incelemiştir. Granger nedensellik test ve Ardışık Gecikmesi 
Dağıtılmış (ARDL) Sınır testi sonuçları, elektrik üretimi ile ekonomik büyüme arasında ilişkinin varlığını göstermektedir.

Vlahinić-Dizdarević ve Žiković (2010), Hırvatistan'da 1993-2006 döneminde, enerji ile ekonomik büyüme arasındaki nedensellik ilişkisini incelemişlerdir. ECM yönteminin uygulandığı çalışmanın ekonometrik modellemesi için; reel GSYIH, sanayi sektörü ve hane halkı enerji tüketimi, petrol tüketimi, birincil enerji tüketimi ve net enerji ithalatı değişkenleri belirlenmiştir. Çalışmanın bulguları, reel GSYİH ile enerji değişkenleri arasında ilişkinin varlığına işaret etmektedir.

Kaplan vd. (2011), Türkiye'de 1971-2006 döneminde enerji tüketimi ve ekonomik büyüme arasındaki nedensellik ilişkilerini incelemişlerdir. Johansen-Juselius Eşbütünleşme ve Granger Nedensellik Test yöntemlerinin kullanıldığı çalışma için; enerji tüketimi, reel GSYİH, reel enerji fiyatları, sermaye, emek değişkenlerini kapsayan ekonometrik model kurulmuştur. Elde edilen bulgular, değişkenler arasında uzun dönemli bir ilişkinin varlığını ve enerji tüketimi ile ekonomik büyüme arasında çift yönlü nedensellik ilişkisinin var olduğunu göstermektedir.

Tiwari (2011), Hindistan'da 1971-2007 döneminde enerji tüketimi, karbon emisyonları ve ekonomik büyüme ilişkisini, Vektör Ardışı (VAR) Granger nedensellik test yöntemini kullanarak incelemiştir. Çalışmada elde edilen bulgular, Hindistan'da belirtilen dönemde enerji tüketiminin, karbon emisyonları ve ekonomik büyüme üzerinde etkili olduğuna işaret etmektedir. Ayrıca, enerji tüketiminin karbon emisyonlarını arttırdığı tespit edilmektedir.

Akpan ve Akpan (2012), Nijerya'da 1970-2008 dönemi için, uzun dönemde elektrik tüketimi, karbon emisyonları ve ekonomik büyüme arasındaki nedensellik ilişkisini çok değişkenli ECM yöntemini kullanarak incelemişlerdir. Çok değişkenli ECM için belirlenen değişkenler, karbon emisyonu, elektrik tüketimi ve ekonomik büyüme oranıdır. Çalışmadaki bulgular, ekonomik büyümeden karbon emisyonlarına doğru tek yönlü bir nedensellik ilişkisinin var olduğunu ortaya koymaktadır.

Farhani ve Rejeb (2012), Ortadoğu ve Kuzey Afrika (MENA) bölgesi ülkelerinde 19732008 döneminde enerji tüketimi, ekonomik büyüme ve karbon emisyonları arasındaki ilişkileri, panel eşbütünleşme ve panel nedensellik ekonometrik test yöntemlerini kullanarak incelemişlerdir. Çalışma sonuçlarına göre, GSYIH ile enerji tüketimi arasında bir ilişki bulunmamakta, fakat kısa dönemde karbon emisyonları ile enerji tüketimi arasında ilişki bulunmaktadır. Elde edilen bu sonuçlara ilâve olarak, uzun dönemde GSYIH ve karbon emisyonu değişkenlerinden enerji tüketimi değişkenine doğru tek yönlü bir nedensellik ilişkisinin var olduğu tespit edilmektedir.

Ru vd. (2012), Çin'de 1960-2008 döneminde, karbon emisyonları ile ekonomik gelişme arasındaki ilişkiyi demateryalizasyon teorisi bağlamında incelemiştir. Çalışmada nicel bir analiz yöntemi kullanılmış olup, bu analiz için kişi başına GSYİH, karbon emisyonları ve karbon emisyonu yoğunlaşması verileri kullanılmıştır. Buna göre Çin'de, çevresel baskılar ile ekonomik gelişme arasında ve karbon emisyonları ile ekonomik gelişme arasında ilişkinin var olduğu tespit edilmektedir.

Chibueze vd. (2013), Nijerya' da, elektrik arzı, fosil yakıt tüketimi, karbon emisyonları ve ekonomik büyüme ilişkisini 1971-2009 dönemi için incelemişlerdir. ARDL eşbütünleşme ve Granger nedensellik test yöntemlerinin kullanıldığı çalışmanın ekonometrik modeli için; reel GSYIHH, elektrik arzı ve fosil yakıt tüketimi değişkenleri kullanılmıştır. Çalışma sonuçlarına göre, karbon emisyonları ile fosil yakıt tüketimi arasında anlamlı bir ilişki bulunduğu tespit edilmektedir.

Apergis ve Danuletiu (2014), seksen ülkede 1990-2012 dönemi için, yenilenebilir enerji tüketimi ile reel GSYİH arasındaki ilişkiyi incelemişlerdir. Çalışmanın ekonometrik uygulaması için Panel Veri Analizi yöntemi kullanılmıştır. Ekonometrik modelleme için; reel GSYİH, yenilenebilir enerji tüketimi değişkenleri kullanılmıştır. Elde edilen bulgulara göre, incelenen 
ülkelerin çoğunda yenilenebilir enerji tüketimi ile reel GSYİH arasında ilişkinin var olduğu tespit edilmektedir.

Arouri vd. (2014), on altı Afrika ülkesinde 1988-2010 döneminde enerji kullanımı ile ekonomik büyüme arasındaki nedensellik ilişsisini incelemiş̧lerdir. Çalışmanın ekonometrik modeli için, enerji kullanımı ve ekonomik büyüme değişkenleri kullanılmış olup, Panel Granger nedensellik test yöntemi uygulanmıştır. Elde edilen bulgular, enerji kullanımı ile ekonomik büyüme arasında ilişkinin var olduğunu göstermektedir.

Ejuvbekpokpo (2014), Nijerya'da 1980-2010 döneminde, karbon emisyonlarının ekonomik büyüme üzerindeki etkilerini, Sıradan En Küçük Kareler (OLS) tahmin yöntemini kullanarak tahmin etmiştir. Tahmin sonuçları, karbon emisyonlarının GSYİH üzerinde olumsuz etkilerinin var olduğunu ortaya koymaktadır. Buna göre, karbon emisyonları, üretimi ve üretkenliği azaltarak ekonomik büyümeyi olumsuz yönde etkilemektedir.

Issaoui vd. (2016), 1990-2010 döneminde Ortadoğu ülkelerinde ve Kuzey Afrika ülkelerinde karbon emisyonlarının ekonomik büyüme üzerindeki etkilerini incelemişlerdir. Çalışmanın ekonometrik modeli için belirlenen değişkenler, karbon emisyonu, kişi başına GSYİH, enerji tüketimi, kentleşme ve yaşam süresi olarak belirlenmiştir. Issaoui vd. (2016), ekonometrik yöntem olarak Tam Modifiye Edilmiş Sıradan En Küçük Kareler (FMOLS) ve Dinamik Sıradan En Küçük Kareler (DOLS) yöntemlerini kullandığı çalışmasındaki sonuçlar, MENA ülkelerinde kısa dönemde kişi başına GSYİH'nin ve enerji tüketiminin karbon emisyonları üzerinde etkili olduğunu göstermektedir. Ayrıca, enerji tüketimi ile ekonomik büyüme arasında nedensellik ilişkisinin var olduğu tespit edilmektedir.

Wolde vd. (2016), Etiyopya'da 1970-2010 döneminde, enerji tüketimi, karbon emisyonları ile ekonomik büyüme arasındaki ilişkiyi incelemişlerdir. Ekonometrik modelleme için; kişi başına reel GSYIH, enerji tüketimi ve karbon emisyonu değişkenleri belirlenmiştir. Zaman serileri analiz yönteminin kullanıldığı çalışmanın sonuçları, enerji tüketiminden ekonomik büyümeye doğru nedensellik ilişkisinin varlığını göstermektedir.

Xiongling (2016), Çin'de, karbon emisyonu ile ekonomik büyüme arasındaki ilişkiyi 1961-2010 dönemi için incelemiştir. Eşbütünleşme, doğrusal ve doğrusal olmayan nedensellik test yöntemlerinin kullanıldığı çalışmanın ekonometrik modeli için; karbon emisyonu ve sabit fiyatlarla GSYİH değişkenleri tercih edilmiştir. Elde edilen bulgular, uzun dönemde GSYİH değişkeninden karbon emisyonu değişkenine doğru tek yönlü bir nedensellik ilişkisinin varlığını göstermektedir.

Aye ve Edoja (2017), gelişmekte olan otuz bir ülkede, ekonomik büyümenin karbon emisyonları üzerindeki etkilerini Dinamik Eşik Panel yöntemini kullanarak incelemişlerdir. Çalışma sonuçları, ekonomik büyümenin yüksek seviyede olduğu dönemde karbon emisyonunun pozitif yönde etkilendiğini göstermektedir. Bu durum, Çevresel Kuznets Eğrisi teorisi ile çelişmektedir. Ayrıca, enerji tüketimi ve nüfus değişkenlerinin karbon emisyonları üzerinde etkili olduğu sonucuna ulaşılmaktadır. Elde edilen bulgular, karbon emisyonlarını ve sürdürülebilir ekonomik büyümeyi azaltmaya dönük düşük karbon teknolojilerinin dönüşümünün gerekli olduğuna işaret etmektedir.

Dees ve Auktor (2017), MENA ülkelerinde, yenilenebilir enerji üretim kapasitesinin ekonomik büyüme üzerindeki etkisini, Genelleştirilmiş En Küçük Kareler (GLS) yöntemini kullanarak incelemişlerdir. 1990-2012 döneminin incelendiği çalışmada, yenilenebilir elektrik üretiminin ekonomik büyüme üzerinde anlamlı ve pozitif bir etkiye sahip olduğu sonucuna ulaşılmaktadır.

Nandakumar vd. (2017), Hindistan'da 1971-2013 döneminde, kişi başına GSYİH ile enerji kullanımı arasındaki ilişkiyi incelemişlerdir. Çalışmanın ekonometrik modellemesi için; kişi başına GSYIHH ve kişi başına enerji kullanımı değişkenleri belirlenmiş̧tir. Ekonometrik yöntem olarak eşbütünleşme, ECM ve Granger nedensellik test yöntemleri uygulanmıştır. Elde 
edilen sonuçlar, Hindistan'da kişi başına GSYİH ile kişi başına enerji kullanımı arasında ilişkinin var olduğunu göstermektedir.

\section{Ekonometrik Yöntem}

$\mathrm{Bu}$ çalışmanın ekonometrik uygulamasında ilk olarak, durağanlık analizi için Dickey Fuller GLS (ERS) birim kök test yöntemi uygulanmıştır. Durağanlık analizinin ardından Johansen eşbütünleşme, OLS tahmin ve ECM Granger nedensellik test yöntemleri kullanılmıştır. Bu ekonometrik yöntemler, ekonomik büyüme ile enerji tüketimi ve karbon emisyonları ilişkisinin varlığını hem uzun dönemde hem de belirtilen ilişsinin yönünü tespit edebilmeyi mümkün kıldığı için kullanılmıştır.

Çalışmadaki serilerin, kendi ortalamaları etrafındaki dağılımlarını görmek için birim kök test yöntemi olarak Dickey Fuller GLS (ERS) birim kök test yöntemi tercih edilmiştir. Buna göre, Elliot vd. (1996), Dickey-Fuller test yöntemini modifiye ederek durağanlık analizi öncesinde serileri GLS tahmin yöntemi regresyonu ile dönüştürerek yeni bir birim kök testi önermişlerdir. Buna göre, önceki birim kök testleri ile kıyaslandığında Dickey Fuller GLS (ERS) olarak adlandırılan yeni birim kök testinin gücünde ve performansında önemli bir artış sağlanmıştır.

Çalışmadaki serilerin, uzun dönemli ilişkilerini tespit etmek amacıyla kullanılan Johansen eşbütünleşme test yöntemi, ikiden fazla değişken olması durumunda tüm eşbütünleşik vektörlerin tahmin edilmesine imkan vermektedir. Serilerde birim kökün var olması durumunda standart asimptotik dağılımın geçerli olmadığı ifade edilmektedir (Dwyer, 2015, s. 1).

Johansen test yöntemi, denklem (1)'de verilen VAR'daki p'nci başlangıç noktasını esas almaktadir;

$$
y_{t}=\mu+A_{1} Y_{t-1}+\ldots+A_{p} Y_{t-p}+\varepsilon_{t}
$$

Denklem (1)'de yt, genel olarak inovasyonların nx1 vektörü olarak I(1) ve $\varepsilon_{\mathrm{t}}$ olarak ifade edilen birinci sıra entegre olmuş değişkenlerin bir nx1 vektörüdür (Hjalmarsson ve Österholm, 2007, s. 4).

Johansen eşbütünleşme testinde var olan eşbütünleşik vektör sayısı, İz istatistik ve Maksimum Özdeğer istatistik değerlerinin belirli bir anlamlılık düzeyine göre anlamlı olup olmadıklarına bakılarak karar verilmektedir.

Çalışmada kullanılan diğer bir ekonometrik yöntem OLS tahmin yöntemi, farklı değişkenler arasındaki ilişkilerin katsayılarını gerçek değerine en yakın bir biçimde tahmin etmeye yarayan doğrusal bir yöntemdir.

OLS yöntemi, regresyon çözümlemelerinde yaygın olarak kullanılan bir tahmin yöntemidir. Bu tahmin yönteminde, gözlenen veriler arasındaki karesel farklılıklar ve bunların beklenen değerleri en aza indirilerek parametre tahmini yapılmaktadır (Van De Geer, 2005, s. 1041).

Çalışmada, son olarak kullanılan ekonometrik yöntem Granger (1969) nedensellik test yöntemidir. $\mathrm{Bu}$ yöntem, iki değişken arasındaki nedensellik ilişkisinin varlığını ve yönünü belirlemek amacıyla kullanılan bir yöntemdir. Granger (1969) nedensellik testine göre, bir Y değişkeni hakkında öngörüde bulunmak bir $\mathrm{X}$ değişkeninin geçmişte sahip olduğu değerler üzerinden gerçekleştirilebiliyorsa bu durumda, "X değişkeni Y değişkeninin Granger nedenidir" sonucuna ulaşılmaktadır. Granger nedensellik testi (2) ve (3) no'lu denklem üzerinden uygulanmaktadır. 


$$
\begin{aligned}
& Y_{t}=\sum_{i=1}^{m} \alpha_{1} Y_{t-i}+\sum_{j=1}^{m} \alpha_{2} X_{t-j}+u_{1 t} \\
& X_{t}=\sum_{i=1}^{m} \beta_{1} X_{t-i}+\sum_{j=1}^{m} \beta_{2} Y_{t-j}+u_{2 t}
\end{aligned}
$$

Denklem (2) ve denklem (3)'te, $\alpha_{1}, \alpha_{2}, \beta_{1}$ ve $\beta_{2}$; eğim katsayılarını, $u_{1 t}$ ve $u_{2 t}$; hata terimlerini, m; gecikme uzunluğu (lag) değerlerini göstermektedir. Her iki denklemdeki eğim katsayılarının istatistiksel olarak anlamlı olması durumunda, ilgili değiş̧kenler arasında Granger nedensellik ilişkisinin var olduğu sonucuna ulaşılmaktadır. Buna göre, Granger nedensellik ilişkisinin olmadığını iddia eden yokluk (null) hipotezinin reddedilmesine karar verilmektedir.

\section{Veri Seti ve Modelin Belirlenmesi}

Çalışmanın ekonometrik uygulaması için kullanılan değişkenlere ait veri seti Dünya Bankası internet sitesinden alınmıştır. Çalışmanın ekonometrik uygulamasında kullanılan seriler ve ayrıntılı bilgiler tablo 1'de verilmiştir.

Tablo 1. Ekonometrik uygulama için kullanılan değişkenler ve veri seti bilgileri

\begin{tabular}{cclc}
\hline Değişken & Dönem & Açılama & Kaynak \\
\hline CO2 & $1971-2014$ & Karbon Emisyonları & Dünya Bankası \\
\hline Y & $1971-2014$ & $\begin{array}{l}\text { Reel Gayri Safi Yurtiçi Hasıla } \\
(2010 \text { Y1lı Sabit Fiyatlarla, US\$) }\end{array}$ & Dünya Bankas1 \\
\hline EC & $1971-2014$ & $\begin{array}{l}\text { Birincil Enerji Tüketimi } \\
\text { (kişi başına petrol tüketimi, kg) }\end{array}$ & Dünya Bankası \\
\hline
\end{tabular}

Bu çalışma, 1971-2014 örnek dönemini kapsamakta olup, bu kapsamda çalışmada Çin için önerilen ekonometrik model, denklem (4)’te gösterilmiştir. Buna göre;

$$
\mathrm{CO}_{t}=\alpha_{0}+\alpha_{1} Y_{t}+\alpha_{2} E C_{t}+\varepsilon_{t}
$$

Denklem (4)'te verilen ekonometrik model için belirlenen değişkenler şunlardır;

CO2: Karbon emisyonlar1

Y: Kişi başına reel GSYİH (2010 yılı sabit fiyatlarla, US\$),

EC: Birincil Enerji Tüketimi (kişi başına petrol tüketimi, kg),

$\alpha_{1}, \alpha_{2} ;$ Eğim katsayıları and $\varepsilon_{t}$, hata terimi.

$\mathrm{Bu}$ çalışmadaki ekonometrik modelin belirlenmesinde, Akpan ve Akpan (2012)'ın, Nijerya'da 1970-2008 dönemi için elektrik tüketimi, karbon emisyonları ve ekonomik büyüme arasındaki ilişkinin incelendiği çalışmasındaki model ile birlikte, Kasperowicz (2015)'in, AB ülkelerinde ekonomik büyüme ile karbon emisyonları ilişkisini 1995-2012 dönemi için incelediği çalışmasındaki model esas alınmıştır.

\section{Ekonometrik Sonuçlar}

Çalışmada öncelikle ekonometrik model için belirlenen değişkenlere ait serilerin logaritmik dönüşümleri esas alınarak serilerin durağanlık analizi, Dickey-Fuller GLS (ERS) birim kök test yöntemi kullanılarak yapılmıştır. Dickey-Fuller GLS (ERS) birim kök testinin uygulanmasında en uygun gecikme uzunluğu değeri Schwarz Bilgi Kriterine göre belirlenmiştir. Seriler, sabitli, sabitli-trendli olmak üzere iki farklı biçimde birim kök testine tabi tutulmuştur. Dickey-Fuller GLS (ERS) birim kök test sonuçları Tablo 2'de gösterilmektedir. 
Tablo 2. Dickey-Fuller GLS (ERS) birim kök test sonuçları

\begin{tabular}{|c|c|c|c|c|c|}
\hline \multirow[b]{2}{*}{ Değişken } & \multicolumn{2}{|c|}{ Düzey } & \multicolumn{2}{|c|}{ Birinci Fark } & \multirow[b]{2}{*}{ Sonuç } \\
\hline & Sabit & $\begin{array}{l}\text { Sabit } \\
\text { Trend }\end{array}$ & Sabit & $\begin{array}{l}\text { Sabit } \\
\text { Trend }\end{array}$ & \\
\hline $\mathrm{CO} 2$ & $0.282(1)$ & $-2.314(1)$ & $-3.454(0) * *$ & $-3.520(0)^{*}$ & $\mathrm{I}(1)$ \\
\hline Y & $0.127(1)$ & $-1.796(2)$ & $-2.872(0) * *$ & $-4.183(0) * *$ & $\mathrm{I}(1)$ \\
\hline $\mathrm{EC}$ & $0.595(1)$ & $-1.461(1)$ & $-3.554(0)^{* *}$ & $-3.823(0)^{* *}$ & $\mathrm{I}(1)$ \\
\hline
\end{tabular}

Tablo 2'deki sonuçlara göre, CO2, Y ve EC olmak üzere tüm değişkenlere ait seriler düzey değerlerine göre durağan olmayıp, serilerin birim kök içerdikleri tespit edilmektedir. Daha sonra, serilerin birinci fark değerlerine göre yeniden birim kök testleri yapıldığında seriler durağan sonuçlanmış, serilerin kendi ortalamaları etrafında dağıldıkları tespit edilmiştir. $\mathrm{Bu}$ sonuçlar, "seriler durağan değildir, birim kök içermektedir" yokluk $\left(\mathrm{H}_{0}\right)$ (null) hipotezinin reddedilmesi gerektiğini göstermektedir.

Çalışmada, birim kök testinin ardından, değişkenlere ait seriler arasındaki uzun dönemli ilişkileri tespit edebilmek amacıyla Johansen eşbütünleşme testi uygulanmıştır. Johansen eşbütünleşme test sonuçları Tablo 3'te gösterilmektedir.

Tablo 3. Johansen eşbütünleşme test sonuçları

\begin{tabular}{|c|c|c|c|c|c|}
\hline \multicolumn{2}{|c|}{ Hipotez } & \multirow{2}{*}{$\begin{array}{c}\text { İz } \\
\text { İstatistik }\end{array}$} & \multirow{2}{*}{$\begin{array}{l}5 \% \text { Kritik } \\
\text { Değer }\end{array}$} & \multirow{2}{*}{$\begin{array}{c}\text { Maksimum } \\
\text { Özdeğer } \\
\text { İstatistiği }\end{array}$} & \multirow{2}{*}{$\begin{array}{c}5 \% \text { Kritik } \\
\text { Değer }\end{array}$} \\
\hline Yokluk & Alternatif & & & & \\
\hline $\mathrm{r} \leq 0$ & $r>0$ & $37.907 * *$ & 29.797 & $25.825^{*}$ & 21.132 \\
\hline $\mathrm{r} \leq 1$ & $r>1$ & 12.082 & 15.495 & 12.064 & 14.265 \\
\hline $\mathrm{r} \leq 2$ & $r>2$ & 0.018 & 3.841 & 0.018 & 3.841 \\
\hline
\end{tabular}

Tablo 3 'te verilen Johansen eşbütünleşme sonuçlarına göre CO2, Y ve EC değişkenlerine ait seriler arasında en fazla bir vektörün eşbütünleşik olduğu tespit edilmektedir. Buna göre, çalışmanın ekonometrik modellemesi için belirlenen $\mathrm{CO} 2$, Y ve EC değişkenlerine ait seriler arasında uzun dönemli bir ilişki olduğu ve belirtilen serilerin uzun dönemde beraber hareket ettikleri tespit edilmektedir. Öte yandan, çalışmanın ekonometrik modellemesi için belirlenen değişkenlere ait serilerin birinci fark değerleri esas alınarak, Johansen eşbütünleşme testi sonrasında çalışma için belirlenen modelin katsayıları OLS yöntemine göre tahmin edilmiştir. OLS tahmin sonuçları Tablo 4'te gösterilmektedir.

Tablo 4. Sıradan en küçük kareler (OLS) tahmin sonuçları

\begin{tabular}{|c|c|c|c|c|}
\hline \multicolumn{5}{|c|}{ Bağımlı Değişken: CO2 } \\
\hline Değişken & Katsayı & $\begin{array}{c}\text { Standart } \\
\text { Hata }\end{array}$ & t-İstatistik & Olasılık \\
\hline $\mathrm{c}$ & -0.0085 & 0.0094 & -0.9024 & 0.3722 \\
\hline $\mathrm{Y}$ & 0.2538 & 0.1229 & $2.0653 *$ & 0.0454 \\
\hline $\mathrm{EC}$ & 0.9684 & 0.1101 & $8.7943 * *$ & 0.0000 \\
\hline R-kare & 0.7327 & \multicolumn{2}{|c|}{ Mean dependent var } & 0.0460 \\
\hline Düzeltilmiş R-kare & 0.7193 & \multicolumn{2}{|c|}{ S. D. dependent var } & 0.0463 \\
\hline Regresyonun S.H.'si & 0.0245 & \multicolumn{2}{|c|}{ Akaike bilgi kriteri } & -4.5094 \\
\hline Sum squared resid & 0.0241 & \multicolumn{2}{|c|}{ Schwarz Kriteri } & -4.3865 \\
\hline Log likelihood & 99.9518 & \multirow{2}{*}{\multicolumn{2}{|c|}{ Durbin-Watson İstatistik }} & 1.9857 \\
\hline F-İstatistik & 54.8212 & & & \\
\hline
\end{tabular}


Tablo 4'te verilen OLS tahmin sonuçlarına göre, Y ve EC bağımsız değişkenlerine ait katsayı tahminlerinin test istatistik değerlerinin $\% 5$ ve $\% 1$ anlamlılık düzeylerine göre istatistiksel olarak anlamlı olduğu tespit edilmektedir. Elde edilen tahmin sonuçlarına göre, Y değişkenindeki \%1'lik artışın CO2 değişkenini \%0.25 birim arttırdığı, EC değişkenindeki \%1'lik artışın CO2 değişkenini \%0.97 birim arttırdığı tespit edilmektedir. Ayrıca belirlilik katsayısının 0.73 olarak sonuçlanması, CO2 bağımlı değişkenindeki değişmelerin \% 73'ü Y ve EC bağımsız değişkenleri tarafından açıklanmaktadır.

OLS tahmin yönteminin ardından çalışmanın ekonometrik modeli ECM yöntemi ile tahmin edilmiştir. ECM yöntemi ile elde edilen Granger nedensellik test sonuçları Tablo 5 'te gösterilmiştir.

Tablo 5. Hata düzeltme modeli (ECM) Granger nedensellik/Block Dışsallık Wald test sonuçları Bağımlı Değişken: CO2

\begin{tabular}{cccc}
\hline Bağımsız Değişken & $\chi^{\mathbf{2}}$ & df & Olasılık \\
\hline $\mathrm{Y}$ & 2.8819 & 1 & 0.0896 \\
$\mathrm{EC}$ & 0.0012 & 1 & 0.9719 \\
\hline \multicolumn{4}{c}{ Bağımı Değişken: $Y$} \\
\hline Bağımsız Değişken & $\chi^{\mathbf{2}}$ & df & Olasılık \\
\hline CO2 & 0.0642 & 1 & 0.8000 \\
EC & 0.0041 & 1 & 0.9490 \\
\hline
\end{tabular}

Tablo 5'te verilen ECM Granger nedensellik test sonuçlarına göre, Y ve EC değişkenleri ile $\mathrm{CO} 2$ değişkeni arasında $\% 5$ anlamlılık düzeyine göre ki-kare test istatistik değerleri anlamlı olmadığ 1 için Granger nedensellik ilişkisi bulunamamıştır. Bu bakımdan ECM Granger nedensellik test sonuçları ile Johansen eşbütünleşme ve OLS tahmin sonuçları birbirinden farkl11ıklar göstermektedir.

Çalışmanın ekonometrik sonuçları genel bir çerçevede değerlendirildiğinde hem OLS tahmin sonuçları hem Johansen eşbütünleşme test sonuçları, Çin'de 1971-2014 döneminde ekonomik büyümenin ve enerji tüketiminin karbon emisyonları üzerinde uzun dönemde etkili olduğunu göstermektedir.

\section{Sonuç}

Ekonomik gelişme ile birlikte, yüksek düzeyde enerji kullanımının çevre kalitesi üzerindeki etkileri tartışılmaktadır. Bu bağlamda, ekonomik gelişme ve büyüme ile birlikte çevresel duyarlılıkları dikkate alan sürdürülebilir ekonomik gelişme ve büyüme yaklaşımları gittikçe önemli hale gelmektedir. Dolayısıyla, ekonomik büyümenin gerçekleştirilmesinin yanı sıra, büyümenin çevre kirliliği üzerindeki olumsuz etkilerinin minimum düzeye indirilmesi, sosyal maliyetlerin azaltılması ve gelecek nesillere daha yaşanabilir sağlıklı bir çevrenin bırakılması önem arz etmektedir. Bu bağlamda, devletin gerekli düzenlemeleri yapması ve çevreye verilen zararların mali ve hukuki yönden uygulanan yaptırımlar ile en düşük düzeye indirilmesi ve bu nedenle ortaya çıkan sosyal maliyetlerin azaltılması gerekmektedir.

Son çeyrek yüzyılda hızlı ve istikrarlı bir ekonomik büyümenin gerçekleştiği Çin'de çevre kirliliği açısından önemli sorunlar ortaya çıkmıştır. Bu nedenle 2014 yılından itibaren çevre kirliliği ile mücadele edilmektedir. Bu kapsamda, 2018 yılında aşırı kömür tüketimi ve taşıt kullanımının meydana getirdiği kirliliğin kontrol edilmesi ve kırsal alanda yoğun olarak kullanılan kömür yerine temiz enerjinin kullanımını yaygınlaştırmayı hedefleyen projelerin desteklenmesi amaçlanmıştır. Bu çerçevede, 2018 yılı için 67 milyar Yuan'ın üzerinde bir 
yatırımın yapılması planlanmış ve hava kalitesini iyileştirmek amacıyla önemli tedbirler alınmıştır.

Bu çalışmada, Çin'de ekonomik büyüme, enerji tüketimi ve karbon emisyonları iliş̧kilerinin incelenmesi için farklı ekonometrik yöntemler uygulanması ve farklı sonuçlara ulaşılması açısından literatüre katkı sağlanması amaçlanmaktadır. Bu çerçevede ekonomik büyüme ve enerji tüketimi ile karbon emisyonları arasındaki ilişkiyi uzun dönemde incelemek için Johansen eşbütünleşme testi kullanılmış, belirtilen ilişkinin yönünü ve düzeyini tespit etmek için OLS tahmin yöntemi uygulanmış ve son olarak ECM yöntemi kullanılarak belirtilen değişkenler arasındaki nedensellik ilişkisinin varlığı incelenmiştir.

Çin'de ekonomik büyüme ve enerji tüketimi ile karbon emisyonları ilişkisinin incelendiği bu çalışmada elde edilen sonuçlar, incelenen ülkede ekonomik büyümenin karbon emisyonları üzerinde etkili olduğunu göstermektedir. Buna göre, çalışmanın literatür kısmında incelenen ekonomik büyüme ve enerji tüketimi ile karbon emisyonları ilişkisinin incelendiği çalışmaların çoğunluğunda elde edilen bulgular ile bu çalışmanın bulguları arasında benzerliklerin bulunduğu tespit edilmektedir.

Çalışmada, ekonometrik yöntem olarak kullanılan Johansen eşbütünleşme testi ve OLS tahmin sonuçlarına göre, Çin'de ekonomik büyüme ve enerji tüketimi ile karbon emisyonları arasında uzun dönemli ve anlamlı bir ilişki tespit edilmektedir. Bu bağlamda, ekonomik büyüme ve enerji kullanımı karbon emisyonlarını pozitif yönde etkilemektedir.

Bu çalışmanın bulguları genel olarak, Çin'de, ekonomik büyümenin ve enerji tüketiminin karbon emisyonları üzerinde etkili olduğuna işaret etmektedir. $\mathrm{Bu}$ bağlamda, Çin için sürdürülebilir büyüme yaklaşımının ne kadar önemli olduğunu ortaya koymaktadır. Bundan sonraki süreçte, Çin ekonomisinin bir yandan ekonomik büyümeyi gerçekleştirirken, diğer yandan çevresel kirlilik ile ilgili gelişmeleri de dikkate alması gerekmektedir.

\section{Kaynakça}

Acaravc1, A. ve Ozturk, I. (2010). CO2 Emissions, energy consumption and economic growth in Turkey. Renewable and Sustainable Energy Reviews, 9(14), 3220-3225.

Akpan, G. E. ve Akpan, U. F. (2012). Electricity consumption, carbon emissions and economic growth in Nigeria. International Journal of Energy Economics and Policy, 4(2), 292-306.

Ang, J. (2007). CO2 Emissions, energy consumption, and output in France. Energy Policy, $10(35), 4772-4778$.

Apergis, N. ve Danuletiu, D. C. (2014). Renewable energy and economic growth: Evidence from the sign of panel long-Run causality. International Journal of Energy Economics and Policy, 4(4), 578-587.

Apergis, N. ve Payne, J. E. (2010). The emissions, energy consumption, and growth nexus: Evidence from the common wealth of independent states. Energy Policy, 38(1), 650-655.

Arouri, M., Youssef, A. B., M'Henni, H. ve Rault, C. (2012). Energy consumption, economic growth and CO2 emissions in Middle East and North African countries. IZA DP No. 6412.

Arouri, M., Youssef, A. B., M'Henni, H. ve Rault, C. (2014). Energy use and economic growth in Africa: A panel Granger-causality investigation. CESifo Working Paper No. 4844.

Aydın, F. F. (2013). CO2 Emissions, renewable energy consumption, population density and economic growth in G7 countries. The Journal of Knowledge Economy \& Management, 2(8), $89-104$. 
Aye, G. C. ve Edoja, P. E. (2017). Effect of economic growth on CO2 emission in developing countries: Evidence from a dynamic panel threshold model. Cogent Economics \& Finance, 5(2017), 1-22.

Chang, C. C. (2010). A multivariate causality test of carbon dioxide emissions, energy consumption and economic growth in China. Applied Energy,87(11), 35333537. https://doi.org/10.1016/j.apenergy.2010.05.004

Chibueze, E. N., Jude, O. C. ve Moses, N. (2013). Electricity supply, fossil fuel consumption, $\mathrm{CO} 2$ emissions and economic growth: implications and policy options for sustainable development in Nigeria. International Journal of Energy Economics and Policy, 3(3), 262271.

Dasgupta, P. ve Heal, G. (1974). The optimal depletion of exhaustible resources. Review of Economic Studies, 41, 3-28.

Dees, P. ve Auktor, G. (2017). Renewable energy and economic growth in the MENA region: empirical evidence and policy implications. Proceedings of the 37th Annual Meetings of MEEA, Chicago.

Dwyer, G. P. (2015). The johansen tests for cointegration. Journal Horizon, 12. http://www. Jerrydwyer.com/pdf/Clemson/Cointegration.pdf (Erişim tarihi: 18.12.2019).

Ejuvbekpokpo, S. A. (2014). Impact of carbon emissions on economic growth in Nigeria. Asian Journal of Basic and Applied Sciences, 1(1), 15-25.

Elliot, G., Rothenberg, T. J., ve Stock, J. H. (1996). Efficient tests for an autoregressive unit root. Econometrica, 64, 813-836.

Eugenio, F. B. ve Roberto, P. C. (2009). Country-specific environmental kuznets curves: A random coefficient approach applied to high-income countries. Estudios de Economia, 1(36), $5-32$.

Farhani, S. ve Rejeb, B. J. (2012). Energy consumption, economic growth and CO2 emissions: evidence from panel data for MENA region. International Journal of Energy Economics and Policy, 2(2), 71-81.

Granger, C. W. J. (1969). Investigating causal relations by econometric models and cross-spectral methods. Econometrica, 3(37), 424-438.

Grossman, G. M. ve Krueger, A. (1995). Economic growth and the environment. The Quarterly Journal of Economics, 2(110), 353-377.

Hjalmarsson, E. ve Österholm, P. (2007). Testing for Cointegration Using the Johansen Methodology when Variables are Near-Integrated, IMF Working Paper No. 07/141

Holtz-Eakin, D. ve Selden, T. (1995). Stoking the fires? CO2 emissions and economic growth. Journal of Public Economics, 1995, 1(57), 85-101.

Issaoui, F., Toumi, H. ve Touili, W. (2016). The effects of carbon dioxide emissions on economic growth, urbanization, And welfare: application to countries in the Middle East and North Africa. The Journal of Energy and Development,1/2(41), 223-252.

Kaplan, M., Ozturk, I. ve Kalyoncu, H. (2011). Energy consumption and economic growth in Turkey: cointegration and causality analysis. Romanian Journal of Economic Forecasting 2/2011: 31-41.

Kasperowicz, R. (2015). Economic growth and CO2 emissions: The ECM analysis. Journal of International Studies, 3(8): 91-98.

Markulev, A. ve Long, A. (2013). On sustainability: an economic appoach. Australian Government Productivity Commission Staf Research Note May 2013. 
http://www.uws.edu.au/_data/assets/pdf_file/0008/473327/Economic_sustainability_discus sion_paper_May_2013.pdf(Erişim tarihi: 10.12.2019).

Menyah, K. ve Wolde-Rufael, Y. (2010). Energy consumption, pollutant emissions and economic growth in South Africa. Energy Economics, 6(32), 1374-1382.

Nandakumar, V. T., Devasia, M. D. ve Thomachan, K. T. (2017). Interaction between energy consumption and economic growth in India. International Journal of ResearchGranthaalayah, 4(5), 62-71.

Niu, S., Ding, Y., Niu, Y., Li, Y. ve Luo, G. (2011). Economic growth, energy conservation and emissions reduction: A comparative analysis based on panel data for 8 Asian-Pacific countries. Energy Policy, 39, 2121-2131.

Obradović, S. ve Lojanica, N. (2017). Energy use, CO2 emissions and economic growth causality on a sample of SEE countries. Economic Research-Ekonomska Istraživanja, 30(1), 511-526.

Panayotou, T. (1993). Empirical tests and policy analysis of environmental degradation at different stages of economic development. Working Paper WP238, Technology and Employment Programme, International Labour Office, Geneva.

Resnick, D. ve Thurlow, J. (2012). Green growth: A win-win approach to sustainable development?. United Nations Univesity. https://unu.edu/publications/articles/green-growtha-win-win-approach.html (Erişim tarihi: 24.12.2019).

Richmond, A. K. ve Kaufmann, R.K. (2006). Is there a turning point in the relationship between income and energy use and/or carbon emissions?. Ecological Economics, 56(2), 176-189.

Ru, X., Chen, S. ve Dong, H. (2012). A study on relationship between CO2 emissions and economic development in China based on dematerialization theory. Energy and Environment Research, 2(2), 37-44.

Selden, T. M. ve Song, D. (1994). Environmental quality and development: Is there a Kuznets curve for air pollution emissions?. Journal of Environmental Economics and Management, 27, 147-162.

Shafik, N. (1994). Economic development and environmental quality: An econometric analysis. Oxford Economic Papers New Series, 46, Special Issue on Environmental Economics (Oct., 1994), 757-773.

Shafik, N. ve Bandyopadhyay, S. (1992). Economic Growth and Environmental Quality: Time Series and Cross-Country Evidence. World Bank Working Paper WPS 904, Washington DC.

Siddiqui, R. (2004). Energy and economic growth in Pakistan. The Pakistan development review. Pakistan Institute of Development Economics, 43(2), 175-200.

Solow, R. (1974). Intergenerational equity and exhaustible resources. Review of Economic Studies, 41, 29-45.

Soytas, U. ve Sarı, R. (2009). Energy consumption, economic growth, and carbon emissions: challenges faced by an EU candidate member, Ecological Economics, 6(68), 1667-1675.

Stern, D. I. (2003). The environmental Kuznets curve. International Society for Ecological Economics Internet Encyclopaedia of Ecological Economics, 1-18.

Stiglitz, J., (1974). Growth with exhaustible natural resources: efficient and optimal growth paths. Review of Economic Studies, 41, 123-137.

Tiwari, A. K. (2011). Energy consumption, CO2 emissions and economic growth: A revisit of the evidence from India. Applied Econometrics and International Development, 11-2(2011), 165189. 
To, H., Wijeweera, A. ve Charles, M. B. (2013). Energy consumption and economic growth the case of Australia. in Australian Conference of Economists.

Ucan, O., Arıcıoğlu, E. ve Yucel, F. (2014). Energy consumption and economic growth nexus: evidence from developed countries in Europe. International Journal of Energy Economics and Policy, 3(4), 411-419.

Van De Geer, S. A. (2005). Least squares estimation. Chichester: John Wiley \& Sons, Ltd.

Vincent, J.(1996). Resource depletion and economic sustainability in Malaysia. Cambridge: Harvard Institute for International Development, Harvard University.

Vlahinić-Dizdarević, N., ve Žiković, S. (2010). The role of energy in economic growth: The case of Croatia. Proceedings of Rijeka Faculty of Economics - Journal of Economics and Business, $28(1), 35-60$.

Wolde, E. T., Mulugeta, W. ve Hussen, M. M. (2016). Energy consumption, carbon dioxide emissions and economic growth in Ethiopia. Global Journal of Management and Business Research (B), 2(16), 1-10.

Xiongling, T. (2016). The relationship between carbon dioxide emission intensity and economic growth in China: cointegration, linear and nonlinear Granger causality. Journal of Resources and Ecology, 7(2), 122-129.

\section{ETİK ve BİLIMSEL İLKELER SORUMLULUK BEYANI}

$\mathrm{Bu}$ çalışmanın tüm hazırlanma süreçlerinde etik kurallara ve bilimsel atıf gösterme ilkelerine riayet edildiğini yazar(lar) beyan eder. Aksi bir durumun tespiti halinde Afyon Kocatepe Üniversitesi Sosyal Bilimler Dergisi'nin hiçbir sorumluluğu olmayıp, tüm sorumluluk makale yazarlarına aittir.

\section{ARAŞTIRMACILARIN MAKALEYE KATKI ORANI BEYANI}

1. yazar katk1 oran1: $\% 100$ 